Article

\title{
Secretory Production of Functional Grouper Type I Interferon from Epinephelus septemfasciatus in Escherichia coli and Bacillus subtilis
}

\author{
Hsuan-Ju Lin ${ }^{1}$, Joan Tang Xiao Joe ${ }^{2,3}$, Wen-Jung Lu ${ }^{1}$, Mei-Ying Huang ${ }^{4}$, Ting-Hsuan Sun ${ }^{1}$, \\ Sheng-Pao Lin ${ }^{1}$, Yi-Chuan Li ${ }^{1}$, Ya-Chin Tsui ${ }^{1}$, Ming-Wei Lu ${ }^{5, *}$ and Hong-Ting Victor Lin ${ }^{1,6, *}$ \\ 1 Department of Food Science, National Taiwan Ocean University, Keelung 20224, Taiwan; \\ angel810801@gmail.com (H.-J.L.); miss350100@gmail.com (W.-J.L.); amysun810922@gmail.com (T.-H.S.); \\ simba32013@yahoo.com.tw (S.-P.L.); dacal852@gmail.com (Y.-C.L.); maggietsui0820@gmail.com (Y.-C.T.) \\ 2 Doctoral Degree Program in Marine Biotechnology, The College of Life Sciences, National Taiwan Ocean \\ University, Keelung 20224, Taiwan; Joan94_0137@live.cn \\ 3 Doctoral Degree Program in Marine Biotechnology, Academia Sinica, Taipei 11529, Taiwan \\ 4 Division of Aquaculture, Fisheries Research Institute, Council of Agriculture, No. 199, Hou-Ih Road, \\ Keelung 20246, Taiwan; myhuang@mail.tfrin.gov.tw \\ 5 Department of Aquaculture, National Taiwan Ocean University, Keelung 20224, Taiwan \\ 6 Center of Excellence for the Oceans, National Taiwan Ocean University, Keelung 20224, Taiwan \\ * Correspondence: mingwei@mail.ntou.edu.tw (M.-W.L.); HL358@ntou.edu (H.-T.V.L.); \\ Tel.: +886-2-24622192 (ext. 5206) (M.-W.L.); +886-2-24622192 (ext. 5121) (H.-T.V.L.); \\ Fax: +886-2-24634203 (H.-T.V.L.)
}

Received: 12 January 2020; Accepted: 19 February 2020; Published: 21 February 2020

\begin{abstract}
Nervous necrosis virus (NNV) results in high mortality rates of infected marine fish worldwide. Interferons (IFNs) are cytokines in vertebrates that suppress viral replication and regulate immune responses. Heterologous overexpression of fish IFN in bacteria could be problematic because of protein solubility and loss of function due to protein misfolding. In this study, a protein model of the IFN- $\alpha$ of Epinephelus septemfasciatus was built based on comparative modeling. In addition, PelB and $\mathrm{SacB}$ signal peptides were fused to the N-terminus of E. septemfasciatus IFN- $\alpha$ for overexpression of soluble, secreted IFN in Escherichia coli (E-IFN) and Bacillus subtilis (B-IFN). Cytotoxicity tests indicated that neither recombinant grouper IFN- $\alpha$ were cytotoxic to a grouper head kidney cell line (GK). The GK cells stimulated with E-IFN and B-IFN exhibited elevated expression of antiviral Mx genes when compared with the control group. The NNV challenge experiments demonstrated that GK cells pretreated or co-treated with E-IFN and B-IFN individually had three times the cell survival rates of untreated cells, indicating the cytoprotective ability of our recombinant IFNs. These data provide a protocol for the production of soluble, secreted, and functional grouper IFN of high purity, which may be applied to aquaculture fisheries for antiviral infection.
\end{abstract}

Keywords: Epinephelus septemfasciatus; interferon; nervous necrosis virus; signal peptide; aquaculture

\section{Introduction}

Epinephelus, one of the largest genera of groupers in the family Serranidae, is a teleost fish often found around reefs. Epinephelus can be quite large (over a meter and a hundred kilograms), which makes them a commercially viable and valuable food source. However, a number of grouper fish species are endangered due to overfishing and poor management of coral reef fisheries. The degradation of the grouper's natural environment necessitates the rapid development of a grouper aquaculture industry. One of the major challenges in grouper aquaculture is viral infections caused by the red-spotted 
grouper nervous necrosis virus (RGNNV) [1-4], which is a non-enveloped icosahedral RNA piscine nodavirus containing two-single-stranded RNA [5,6], resulting in high mortality rates $(80-100 \%)$ of affected larvae, juveniles, and some adults in $>120$ species of cultured marine fish worldwide [7-9].

Huge losses occur worldwide in the grouper aquaculture industry every year due to NNV infection [2,9]. Although various vaccines have been developed, such as formalin-in activated and virus-like particle vaccines [10-13], it might be relatively difficult to inject the vaccines into grouper larvae and juveniles [14], which are the primary targets of RGNNV infections. Another approach to reduce RGNNV is interferon (IFN) introduction to fish, which was reported to prevent viral infection in vivo and in vitro [3,15-18]. IFNs are secretory cytokines in vertebrates involved in the inhibition of virus replication and modulation of immune responses [19]. To date, three types of IFNs have been identified (type I, II, III): Type I/III IFNs are induced by viral infections, whereas type II IFNs are induced by mitogenic or antigenic stimuli $[19,20]$. Upon viral infection, infected cells secrete type I IFN $\alpha / \beta$, and these IFNs are believed to protect other unaffected cells from viral infection by inducing the expression of many genes, some of which encode antiviral proteins, such as double-stranded RNA (dsRNA)-activated protein kinase [21], 2', $5^{\prime}$-oligoadenylate synthetase (OAS) [22], and Mx proteins [23].

For commercial and industrialized purposes, recombinant IFNs from Epinephelus septemfasciatus have been produced and were shown to up-regulate $m x$ expression and provide protection against NNV [15]. The grouper and salmon IFNs could up-regulate Mx gene expression in grouper kidney (GK) cells and show antiviral activities in Malabar grouper larvae infected with NNV [3], and pretreatment of IFN- $\alpha 2 \mathrm{a}$ at $48 \mathrm{~h}$ prior to NNV infection could significantly increase the survival rate of zebrafish [24]. However, overexpression of eukaryotic IFNs in E. coli could be challenging as IFNs may not fold properly and precipitate into inclusion bodies during expression $[3,25,26]$. Solubilization of IFNs from inclusion bodies using denaturing agents or detergents have been adapted to refold and recover the biological activities of recombinant IFNs, but it is time-consuming, not environmentally-friendly, and is relatively ineffective. In addition, the recovery of cytosolic recombinant IFNs requires additional processing, such as cell disruption and protein purification [3], which increases production costs and time. In this study, a cell-disruption-free strategy for the production of soluble recombinant grouper IFN has been investigated and biological activities of the IFN were evaluated.

\section{Results and Discussion}

\subsection{Multiple Sequence Alignment and Protein Modeling of Grouper IFN- $\alpha$}

IFNs are small helical cytokines in vertebrates that are involved in inhibition of virus replication and modulation of immune responses [18]. Using Clustal [27], multiple sequence alignment of the D. rerio IFN1 and IFN2, E. coioides IFN, and E. septemfasciatus IFN was performed, as shown in Figure 1.

Nineteen of the 178 amino acid residues in E. septemfasciatus IFN were indicated as the fully conserved residues in the aligned protein sequences (the ${ }^{* * \prime}$ symbol). BLASTP [28] indicated that the IFN- $\alpha$ from E. septemfasciatus (178 amino acid residues) shares a 33\% identity with IFN1 (185 amino acid residues) from Danio rerio (zebra fish), whose protein structure contains one disulfide bridge [29]; In addition, the IFN1 from $D$. rerio is the protein with a determined 3D structure which shares the best sequence identity with the IFN- $\alpha$ from E. septemfasciatus. BLASTP [28] indicated that IFN- $\alpha$ from $E$. septemfasciatus shares $23 \%$ identity with IFN2 (181 amino acid residues) from Danio rerio. BLASTP [28] determined that the IFN- $\alpha$ from E. septemfasciatus shares $94 \%$ identity with type I IFN (178 amino acid residues) from Epinephelus coioides. In IFN2 from Danio rerio, Glu163(F) interacts with both helices $\mathrm{C}$ and E, while Val165(F) and $\operatorname{Arg} 166(F)$ interact with both the D helix and the AB loop [29]. It is possible that the corresponding amino acid residues in E. septemfasciatus IFN- $\alpha$ have the same roles in protein folding.

A protein model of the IFN- $\alpha$ of E. septemfasciatus was built based on comparative modeling by using Chimera [30] and Modeller [31], as shown in Figure 2. The IFN- $\alpha$ of E. septemfasciatus shares a sequence identity of $33 \%$ with the interferon 1 of zebrafish (Danio rerio), with an E value of $2 \times 10^{-29}$. 
The protein structure modeling of the mature form (removal of the predicted signal peptide) of IFN- $\alpha$ of E. septemfasciatus ( $\triangle 20 \mathrm{IFN}-\alpha$ ) was built based on the 3D structure of the zebrafish interferon 1 (PDB databank 3PIV) [29], whose 3D structure was solved using X-ray diffraction with a resolution of $2.09 \AA$. The model we built for E. septemfasciatus IFN- $\alpha$ had a GA341 of 1.00, zDOPE of -1.56, estimated RMSD of 1.544, and estimated overlap (3.5 $\AA$ ) of 0.943 . Results for models with a GA341 greater than 0.7 and negative zDOPE value are relatively reliable $[30,32]$.

\begin{tabular}{|c|c|c|c|}
\hline D. rerio IFN2 & 1 & --MEFWQFVAFLCPALFFAHITSKPTNCFM---RRKHVKTAYSLLESMGG & 45 \\
\hline D. rerio IFN1 & 1 & MRTQMWTYIFV--IYVILQSQSSASTCEWLGR-YRIITTESLNLLKNMGG & 47 \\
\hline E. coioides type I IFN & 1 & ----MLSRILLVLLSLSLYSVGSSLSCRWVDHKERQHSEESLALLDTMAS & 46 \\
\hline E. septemfasciatus IFN- $\alpha$ & 1 & ----MLSRILLVLLSLSLYSAGSSLSCRWVDHKFRQHSEDSLALLDTMAS & 46 \\
\hline & & $: \quad: \quad: \quad:$ & \\
\hline D. rerio IFN2 & 46 & LFPRECLK--ENVRITFPKYALQSNNSNQKTGVAKAVYKIMDHIDELFAN & 93 \\
\hline D. rerio IFN1 & 48 & K--------YADLETPFPSRLYTLMDKSKVEDQVKFLVLTLDH I IHLMDA & 89 \\
\hline E. coioides type I IFN & 47 & NSTNSTEDAEVDDTVSFPNHLYSQASKASAEDKVAFTVQILEEMVALLEG & 96 \\
\hline E. septemfasciatus IFN- $\alpha$ & 47 & NSTNSTEDAEVDDTVSFPNRLYSQASKASAEDKVAFTVQILEEMVALLEG & 96 \\
\hline & & 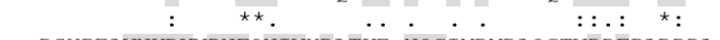 & \\
\hline D. rerio IFN2 & 94 & --DSYPEAWNKRKVDNFQNIVYRLTKE-NQCIMRMRAQGTVDDFPARDDA & 140 \\
\hline D. rerio IFN1 & 90 & REHMNSVNWDQNTVEDFLNILHRKSSDLKECVARYAKPAHKESYE---IR & 136 \\
\hline E. coioides type I IFN & 97 & --GYSSASWEENTEENFLSVVSRQAVGLRSCTVHHKESKKLHMYF---KR & 141 \\
\hline E. septemfasciatus IFN- $\alpha$ & 97 & 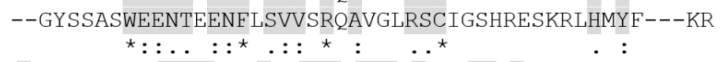 & 141 \\
\hline D. rerio IFN2 & 141 & LKSYENKLATLLRNKDNSFCAWEVVRHELLGVLSDI IQPKL-------- & 181 \\
\hline D. rerio IFN1 & 137 & IKRHERTLKKILKKKQYSAEAWEQIRRVVKSHLQRMDIIASNARVNPRV & 185 \\
\hline E. coioides type I IFN & 142 & L------SSHVLEQMGHSAEAWELIRREMKSHLKRVDQLLLSN------ & 178 \\
\hline E. septemfasciatus IFN- $\alpha$ & 142 & L------SSHVLEQMGHSAEAWELIRREMKTHLKRVDQLLLSN------ & 178 \\
\hline & & $\star \star \star \star \star \quad: \star::$ & \\
\hline
\end{tabular}

Figure 1. Multiple alignment of the interferons from Danio and Epinephelus. Multiple alignment of amino acid sequences of Interferon (IFN)2 from D. rerio (UniProtKB: A8E6E2), IFN1 from D. rerio (UniProtKB: Q8AY12), type I IFN from E. coioides (UniProtKB: M9WVF6), and IFN- $\alpha$ from E. septemfasciatus (UniProtKB: E9RH07). The different sequences have been submitted to a multiple alignment using the Clustal. The following three characters are used to highlight conserved amino acids: ${ }^{* \prime}$ indicated positions which have a single, fully conserved residue; ' $:$ ' indicated conservation between groups of strongly similar properties; '.' indicated conservation between groups of weakly similar properties.

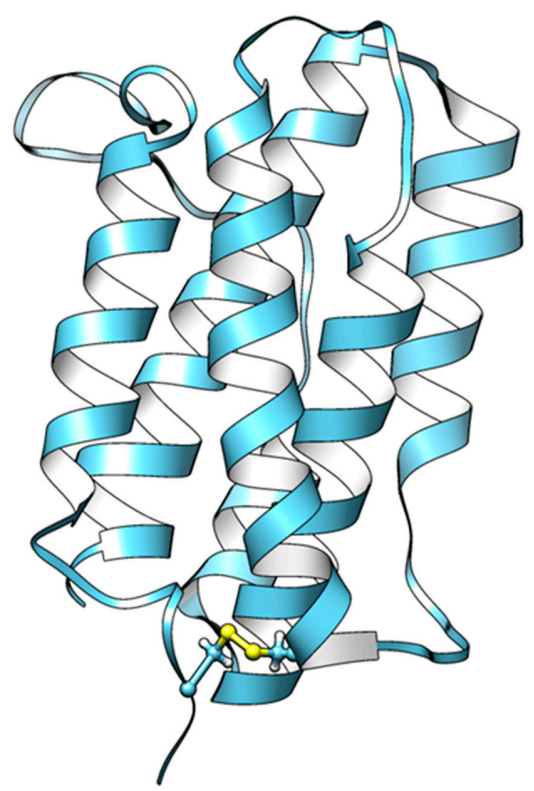

Figure 2. Protein model of the type I IFN- $\alpha$ from E. septemfasciatus. The IFN- $\alpha$ model was built based on the 3D structure of the interferon 1 from Danio rerio (PDB 3PIV) by using Chimera and Modeller.

As shown in Figure 2, six $\alpha$-helices arranged in an antiparallel bundle manner to form the core structure were observed in the IFN- $\alpha$ model. As expected, this model contains one intramolecular disulfide bridge (as shown in yellow) to connect the N-terminal helix A to helix D, and the helix F may 
interact directly with the receptor [29]. A larger loop was observed between helix A and helix B in the protein modeling E. septemfasciatus IFN- $\alpha$ (amino acid residues 44 to 64 ) as compared to the protein structure of interferon 1 from zebrafish.

\subsection{Strategy for Production of Secreted IFN- $\alpha$ in E. Coli and B. Subtilis}

The type I IFN- $\alpha$ from E. septemfasciatus has two cysteines at position 23 and 125 of the polypeptide chain. Disulfide bond is crucial for the stability of final protein structures by decreasing the conformation freedom of the random coils, and the entropy for the reaction to ordered, native 3D structure of a protein is less negative in the presence of a disulfide bond. As a result, mispaired cysteine residues could therefore lead to misfolding and non-functional proteins [33]. Previous studies of IFN indicate that this disulfide bond may alter activity [34-36], and mispaired cysteines can cause misfolding, aggregation and ultimately result in low active protein yields [37-39]. This study aimed to overexpress a functional, soluble IFN- $\alpha$ from E. septemfasciatus in bacteria hosts, such as E. coli and B. subtilis. Our strategy was to translocate the recombinant IFN- $\alpha$ from the cytosol, a reducing environment, into the cell periplasm (E. coli) or extracelluar space (B. subtilis), both of which are oxidizing compartments; suitable for the disulfide-bond formation, which could benefit the folding, stability and solubility of IFN- $\alpha$. Previous reports demonstrate that disulfide oxidoreductases and isomerases located in the E. coli periplasm catalyze the formation of disulfide bonds enabling the accumulation of properly folded, soluble protein; making the periplasm an ideal compartment for the expression of therapeutic proteins [38]. In addition, a gene cluster which putatively encodes disulfide oxidoreductases for the catalysis of disulfide bonds has been reported in B. subtilis, although their substrates are unknown [40].

IFN- $\alpha$ from E. septemfasciatus is predicted to have signal peptides in the N-terminus $[15,41]$. In this study, we used the SignalP 4.1 Server to predict the location and length of the signal peptide in the E. septemfasciatus IFN- $\alpha$ [42]. The results indicate that a signal peptide is contained in the first 20 amino acids of the N-terminus of IFN- $\alpha$, similar to type I interferon from E. coioides [41]. The mature form of IFN- $\alpha(\Delta 20)$ overexpression in $E$. coli was fused, in the N-terminus, with the PelB signal peptide from the pectatelyase B of Erwinia carotovora (Peptide sequence: MKYLLPTAAAGLLLLAAQPAMA) (Figure 3), which translocates recombinant IFN- $\alpha$ into periplasm space of $E$. coli during protein overexpression. In addition, the mature form of IFN- $\alpha(\Delta 20)$ overexpression in B. subtilis was fused, in the N-terminus, with a SacB signal peptide from the levansucrase of $B$. subtilis (Peptide sequence: MNIKKFAKQATVLTFTTALLAGGATQAFA) (Figure 3), which would lead recombinant IFN- $\alpha$ excretion into the extracellular space during protein production.

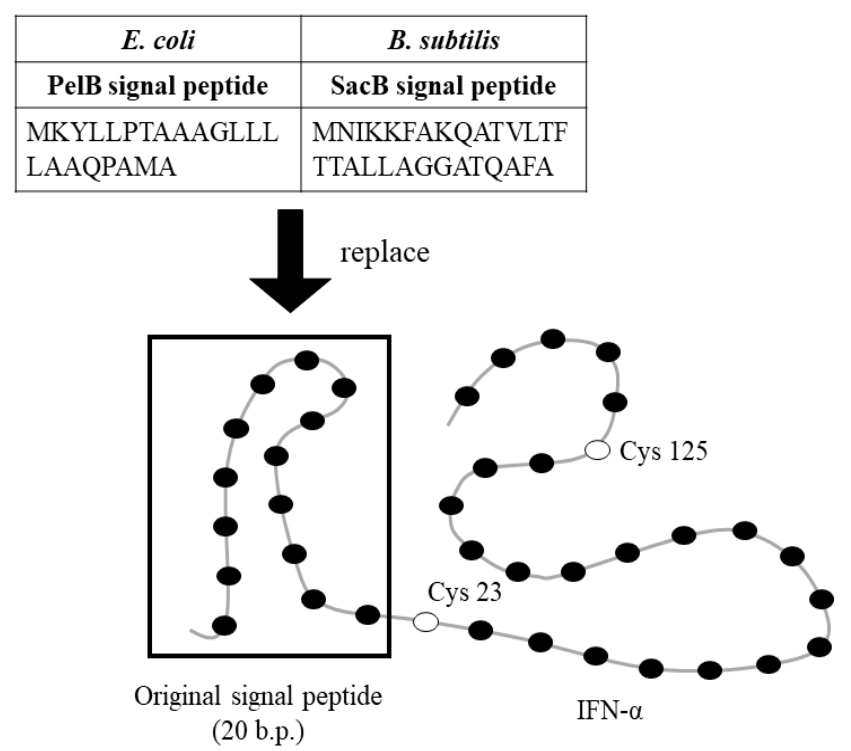

Figure 3. The design of recombinant IFN construction. 


\subsection{Effect of Inducing Time for IFN- $\alpha$ Overexpression}

Pilot experiments were adapted to evaluate IFN- $\alpha$ overexpression at $18,24,30,37$, and $42{ }^{\circ} \mathrm{C}$. Cells at $24{ }^{\circ} \mathrm{C}$ have the highest overexpression of IFN- $\alpha$ (data not shown); therefore, $24^{\circ} \mathrm{C}$ was used for all further experiments. The recombinant IFN- $\alpha$ overexpression was further investigated at different induction time $(3,6,9$, and $12 \mathrm{~h})$. E. coli cells harboring pET-IFN plasmids were induced for various times at $24{ }^{\circ} \mathrm{C}$. Cells were harvested at each time point for protein purification. Soluble IFN- $\alpha$ was obtained from the cells using osmotic shock and purified using affinity chromatography.

The overexpression of IFN- $\alpha$, with an estimated molecular weight of $18 \mathrm{kDa}$, was analyzed by using gel-electrophoresis and the highest level of IFN- $\alpha$ expression in E. coli cells was observed at $12 \mathrm{~h}$ (Figure 4A); E. coli cells tended to lyse when the induction time exceeded $15 \mathrm{~h}$. B. subtilis harboring pHT-IFN plasmid was induced at $3,6,9$, and $12 \mathrm{~h}$ at $24{ }^{\circ} \mathrm{C}$; cells were harvested at each time point for protein purification. Soluble IFN- $\alpha$ was collected from the cell culture supernatant and purified using affinity chromatography. IFN- $\alpha$ was analyzed using gel-electrophoresis, with the IFN- $\alpha$ peaking at $9 \mathrm{~h}$ (Figure 4B). Both proteins were confirmed by either Western blot or peptide mass fingerprinting (data not shown). Periplasmic and extracellular secretion of overexpressed proteins offer several key advantages for protein production, for example, a better target protein purity due to the reduction impurities from other bacterial proteins and nucleic acids [43], and an oxidizing environment, such as periplasm and extracellular space, which facilitates disulfide bond formation for correct protein folding [44]. As shown in Table 1, overexpressed fish interferons in bacterial hosts can form inclusion bodies or insoluble forms, thus requiring further recovery procedures, such as protein denaturation and refolding, to obtain functional interferons. Kakeshita, et al. [45] exploited the AmyE signal peptide in a B. subtilis system for human hIFN- $\alpha 2 \mathrm{~b}$ overexpression with a yield of $1.64 \mathrm{mg} / \mathrm{L}$. In addition, modifications of in the C-terminus of SecA protein in B. subtilis overexpression hosts enhanced the extracellular levels of hIFN- $\alpha 2 b$ up to 2.2 -fold. In this study, overexpression, extraction, and purification of IFN- $\alpha$ from the periplasmic space of $E$. coli gave a yield of $6 \mathrm{mg}$ per L culture. Recovery and purification of IFN- $\alpha$ from the growth media of B. subtilis produced $1.3 \mathrm{mg}$ per L culture. Other strategies, such as co-expression of chaperons and the construction of IFN fused with soluble tag proteins (to increase the solubility of recombinant IFN) have been tested [46,47]. Co-expression of E. coli chaperones, such as GroEL/ES, failed to increase IFN solubility at $37^{\circ} \mathrm{C}$ but managed to decrease the inclusion body formation up to $62 \%$ at $25^{\circ} \mathrm{C}$ [46]. Fusing IFN with a soluble tag (e.g., Small Ubiquitin-like Modifier; SUMO) could improve the solubility of IFN, but the removal of a large, soluble tags requires additional protein purification steps [47].

Table 1. Overexpression of recombinant fish IFNs in heterologous hosts.

\begin{tabular}{|c|c|c|c|c|c|c|}
\hline IFNs & Source & Signal Peptides & Expression Host & $\begin{array}{c}\text { Recombinant IFN } \\
\text { Location }\end{array}$ & $\begin{array}{l}\text { Yield }^{\text {a }}(\mathrm{mg} / \mathrm{L} \\
\text { Culture) }\end{array}$ & References \\
\hline IFN & D. rerio & none & E. coli & Cytosolic & Insoluble & [18] \\
\hline IFN- $\alpha$ & E. septemfasciatus & none & E. coli & Cytosolic & Soluble & [15] \\
\hline IFN- $\alpha$ & E. septemfasciatus & none & E. coli & Cytosolic & Insoluble & [3] \\
\hline IFN- $\alpha$ & E. septemfasciatus & $\mathrm{SacB}$ & B. subtilis & Extracellular & 1.3 & This study \\
\hline IFN- $\alpha$ & E. septemfasciatus & PelB & E. coli & Periplasmic & 6.0 & This study \\
\hline
\end{tabular}

${ }^{a}$ Yield of soluble recombinant IFNs. 
(A)

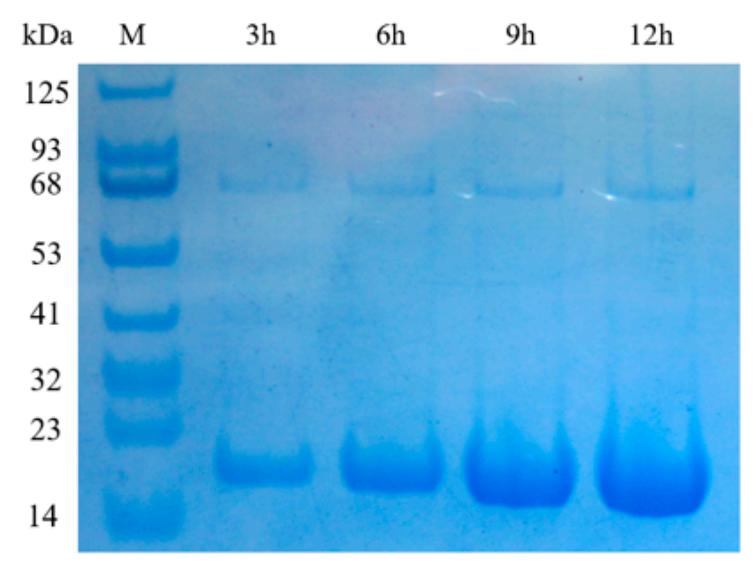

(B)

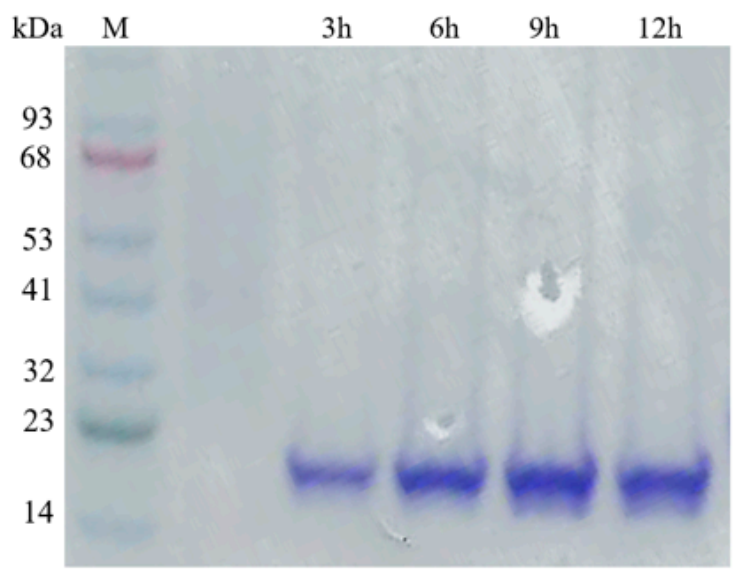

Figure 4. SDS-PAGE of the purified IFN- $\alpha$ from (A) E. coli and (B) B. subtilis overexpression systems at various induction time. Lane $\mathrm{M}$, protein marker. E. coli and B. subtilis cells harboring plasmids encoding IFN were induced by $0.2 \mathrm{mM}$ IPTG at $24^{\circ} \mathrm{C}$ for $3,6,9,12 \mathrm{~h}$.

\subsection{Cytotoxicity of the Recombinant IFN- $\alpha$ Against Grouper Head Kidney Cell}

Cytotoxicity of recombinant IFN- $\alpha$ was evaluated by using MTT assays. Grouper head kidney GK cells incubated with E-IFN at all tested concentrations $(1,5,10,20 \mu \mathrm{g} / \mathrm{mL})$ exhibited more than $85 \%$ cell viability at 24 and $48 \mathrm{~h}$ and more than $95 \%$ at $72 \mathrm{~h}$ (Figure $5 \mathrm{~A}$ ). GK cells incubated with B-IFN at all tested concentrations had more than $90 \%$ cell viability 24,48 , and $72 \mathrm{~h}$ (Figure 5B). According to ISO 10993-5, neither IFN would be considered to be cytotoxic as cell viability is greater than 70\% [48]. In addition, phase-contrast microscopic images of GK cells incubated with recombinant IFN- $\alpha$ from both E. coli and B. subtilis had no significant differences in cell morphology or growth when compared to control group (data not shown).

Kuo [3] compared the anti-NNV effects of different recombinant fish type I interferons (E. septemfasciatus, gIFN; Salmo salar, Sifn; Dicentrarchus labra, sbIFN; Oreochromis niloticus, tpIFN). In cytotoxicity tests, the cell survival rate of gIFN, sIFN, sbIFN, and tpIFN at $10 \mu \mathrm{g} / \mathrm{mL}$ was reduced by approximately 4.3-, 6.0-, 2.0-, and 2.5-fold when compared with control. Our data indicates that secreted E-IFN and B-IFN at up to $20 \mu \mathrm{g} / \mathrm{mL}$ had very little cytotoxic effects in GK cells, indicating that this strategy could be effective for IFN production lacking cytotoxic properties. 
(A)

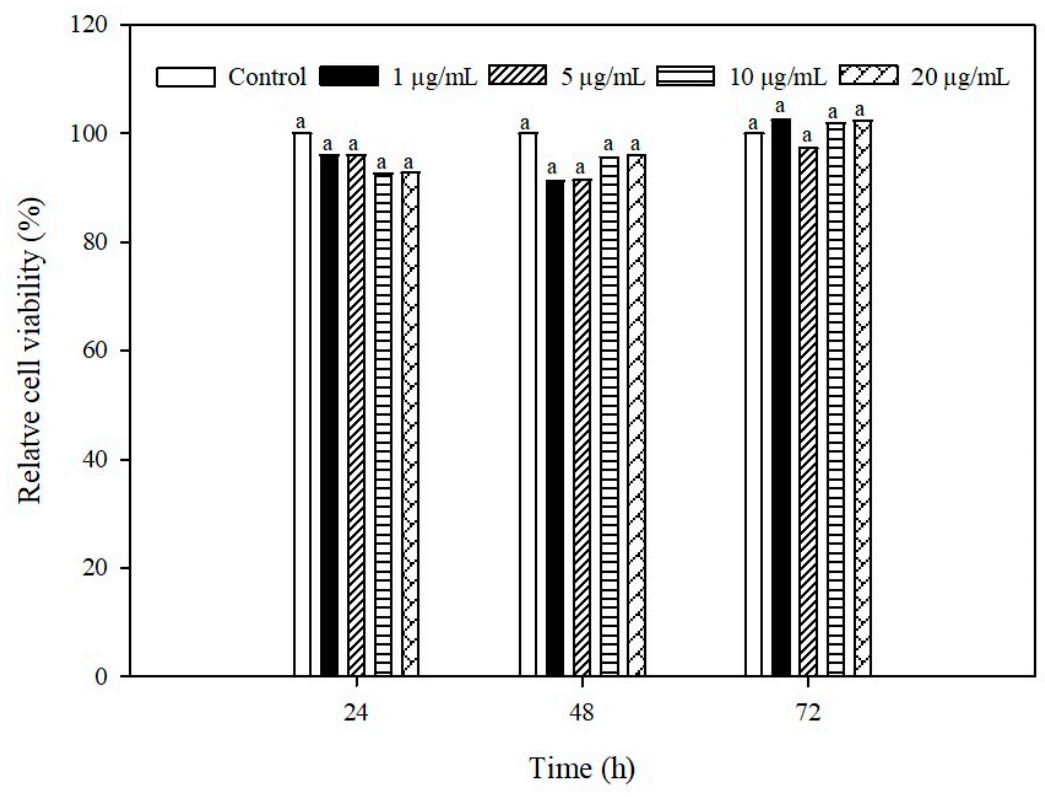

(B)

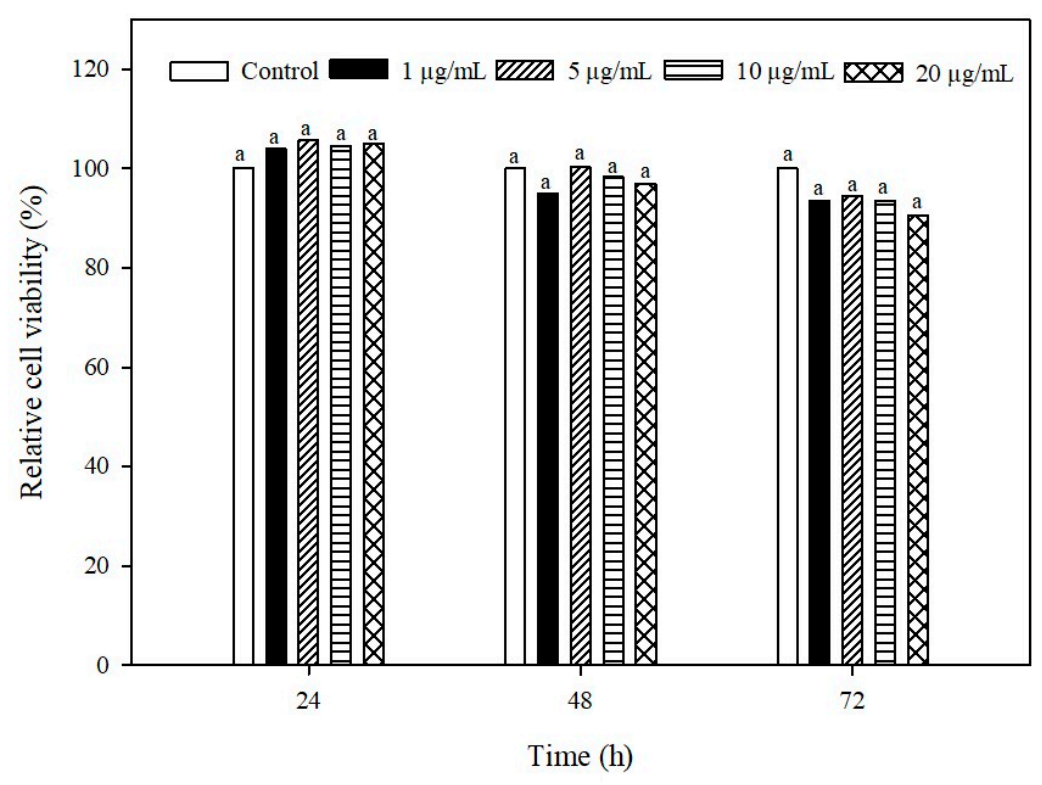

Figure 5. Cytotoxicity of the IFN- $\alpha$ overexpressed in (A) E. coli (B) B. subtilis against grouper kidney (GK) cells by MTT assay. The GK cells were incubated with E-IFN for 24,48 , and $72 \mathrm{~h}$ prior to MTT assay. The O.D. at $540 \mathrm{~nm}$ of each group was compared to the untreated control cells. Data are expressed as mean $\pm \mathrm{SD}(\mathrm{n}=3)$. Different letters at the top of the bars are significantly different $(p<0.05)$.

\subsection{Recombinant IFN- $\alpha$ Stimulated Mx Gene Expression}

RT-PCR experiments were used to confirm whether E-IFN and B-IFN could induce expression of the Mx protein, a member of the GTPase family with antiviral functions [49]. GK cells were treated with $1 \mu \mathrm{g} / \mathrm{mL}$ of E-IFN and B-IFN, individually, for 3, 6, and $12 \mathrm{~h}$, followed by total RNA extraction and analysis of $M x$ gene expression using RT-qPCR.

We observe that E-IFN increases $M x$ gene expression by 5-, 4-, and 2-fold at 3, 6, and $12 \mathrm{~h}$, respectively; in addition, B-IFN increases $M x$ gene expression by 4.2-, 3.2-, and 2.5- fold at 3, 6, and $12 \mathrm{~h}$, respectively (Figure 6). The peak expression of $M x$ gene was achieved when GK cells were incubated with B-IFN and E-IFN for $3 \mathrm{~h}$, followed by decreased expression at 6 and $12 \mathrm{~h}$. These results demonstrate that E-IFN and B-IFN can stimulate GK cells to express the $M x$ gene. 


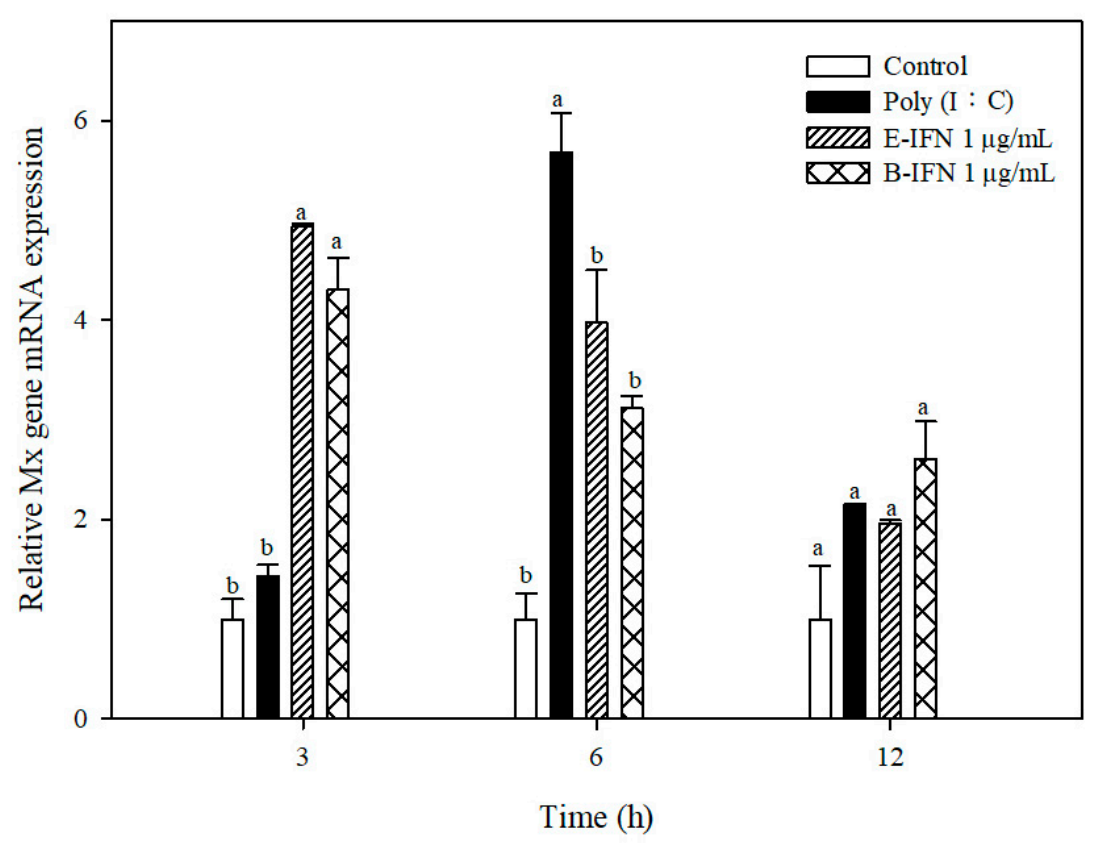

Figure 6. $M x$ gene expression in the GK cells treated with recombinant IFNs. $M x$ gene expression at 3,6 , and $12 \mathrm{~h}$ in GK cells treated with $50 \mu \mathrm{g} / \mathrm{mL}$ of poly(I:C) or $1 \mu \mathrm{g} / \mathrm{mL}$ of E-IFN and B-IFN were measured by real-time PCR. The results were normalized against $\beta$-actin gene and data of triplicate samples were expressed as the mean fold increase relative to the control. Cells cultured with medium; $2^{-\Delta \Delta C T}$ method. Data are expressed as mean \pm SD from triplicate experiments. Different letters in each grouped bars indicated significant differences $(p<0.05)$.

Previous results demonstrate that functional recombinant IFNs increase $M x$ gene expression. GK cells treated with recombinant Sevenband grouper IFN (SgIFN) for 3, 6, and $24 \mathrm{~h}$ increased $M x$ gene expression by 6-, 3.7-, and 2.1-fold, respectively [15]. Mandarin fish cells (MFF-1 cells) incubated with recombinant zebrafish type 1 interferon for 4, 12, and $24 \mathrm{~h}$ also increase Mx gene expression by 4-, $16-$, and 7 -fold at 4,12 , and $24 \mathrm{~h}$.

\subsection{Antiviral Effects of Recombinant IFN in GK Cells}

To determine whether E-IFN and B-IFN inhibit viral infection, antiviral tests against NNV were performed. Thus, antiviral experiments using GK cells were performed using recombinant IFN at different stages, pre-treatment and co-treatment, with NNV infection. GK cells in the pretreatment group were incubated with E-IFN or B-IFN for $24 \mathrm{~h}$ prior to NNV infection. GK cells in the co-treatment group were incubated with IFN and NNV simultaneously. The relative survival rates of the GK cells were evaluated by using an MTT assay at 24 and $48 \mathrm{~h}$ after exposure to virus.

As shown in Figure 7, GK cells pretreated with $1 \mu \mathrm{g} / \mathrm{mL}$ E-IFN and B-IFN exhibited significantly higher relative survival rates at 24 and $48 \mathrm{~h}$ after exposure to NNV when compared with untreated cells. GK cells pretreated with E-IFN or B-IFN showed no significant differences on cell survival rates when compared with control cells (No NNV infection) at $48 \mathrm{~h}$ after exposure to NNV, while untreated cells exhibited a relative survival rate of $29 \%$ when challenged with NNV. GK cells treated with E-IFN or B-IFN with NNV had significant differences in survival rates when compared with untreated cells. GK cells co-treated with E-IFN and B-IFN exhibited relative survival rates of more than $80 \%$ at 24 and $48 \mathrm{~h}$ when compared with the control group. 


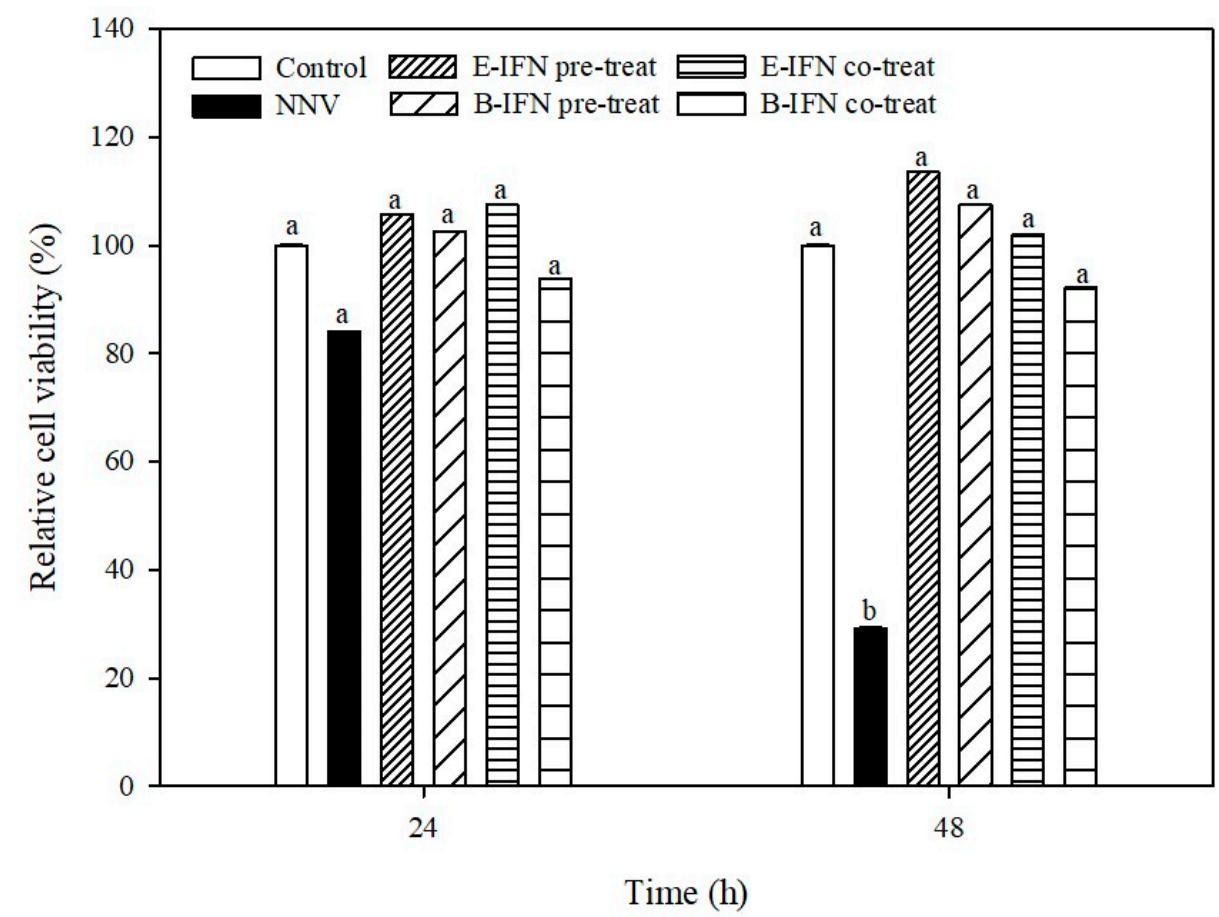

Figure 7. The antiviral effects of the IFNs overexpressed in E. coli and B. subtilis in the pre-treatment and co-treatment to the GK cells. The GK cells were pre-treated and co-treated with NNV (104.5 TCID50/0.1 mL, 1:100 diluted, $100 \mu \mathrm{L} /$ per well) and IFN at $1 \mu \mathrm{g} / \mathrm{mL}$ for 24 and $48 \mathrm{~h}$. The cell viability was determined by MTT assay. Data are expressed as mean \pm SD of triplicate samples, and Different letters in each grouped bars indicated significant differences $(p<0.05)$.

Kuo's studies demonstrated that gIFN, sIFN, sbIFN, tpIFN (Epinephelus septemfasciatus, gIFN; Salmo salar, sIFN; Dicentrarchus labra, sbIFN; Oreochromis niloticus, tpIFN) could protect GK cells from NNV infection. In their pretreatment group, cell survival rate at $24 \mathrm{~h}$ was more than $50 \%$; sIFN, gIFN, and tpIFN had poor cell survival rates $(\sim 25 \%)$ at $48 \mathrm{~h}$. In the co-treat group, the cell survival rate of all groups were more than $80 \%$ after $24 \mathrm{~h}$. At $48 \mathrm{~h}$, sIFN, gIFN, and tpIFN cell survival rate was reduced to $\sim 50 \%$. The results indicated that type I interferon could protect GK cells from virus infection [3]. Ooi, et al. [50] used E. coli to express recombinant Atlantic salmon type 1 interferon (rSasaIFN- $\alpha 2$ ). In cytopathic experiments, $0.78 \mathrm{ng} / \mathrm{mL}$ rSasaIFN- $\alpha 2$ protected cells from virus attack with a cell survival rate greater than $50 \%$. Our data demonstrates that GK cells pretreated or co-treated with our recombinant IFN- $\alpha$ possess higher antiviral activities, indicating that this protocol could be effective when applied to aquacultures for antiviral infections.

\section{Materials and Methods}

\subsection{Virus, Bacterial Strains, and Media}

E. coli $\mathrm{C} 43\left(\mathrm{~F}^{-}\right.$ompT gal dcm hsdSB $\left(\mathrm{r}_{\mathrm{B}}{ }^{-} \mathrm{m}_{\mathrm{B}}{ }^{-}\right)$) [51] and B. subtilis WB800N (Mobitec $\mathrm{GmbH}$, Göttingen, Germany) was used for protein expression. Luria-Bertani (LB) broth (Difco) was used in bacterial culture. The grouper head kidney cell line (GK cell line) established from the kidney tissue of the yellow grouper Epinephelus awoara was maintained at $28^{\circ} \mathrm{C}$ in Leibovitz's L-15 medium (L-15; Gibco, Waltham, MA, USA) supplemented with $10 \%$ fetal bovine serum (FBS) (Thermo Fisher Scientific, Waltham, MA, USA) [52]. NNV was originally isolated from a diseased Malabar grouper (Epinephelus malabaricus) in a hatchery in southern Taiwan and was propagated on the grouper fin (GF-1) cell line in L-15 media with $5 \% \mathrm{FBS}$ at $28{ }^{\circ} \mathrm{C}$ [53]. 


\subsection{Cloning of ifn}

The cDNA of ifn gene was cloned from E. septemfasciatus mRNA by using reverse transcription PCR. The ifn gene amplified by using the primers 5'-AAAACCGGATCCGAGCAGTCTG AGCTGTCGTTGG-3' and 5' ${ }^{\prime}$ AAACCCCTCGAGGTTGCTCAGCAGCAGCTGGT- $3^{\prime}$ for E. coli and 5' - AAAACCGGATCCATGAGCAGTCTGAGCTGTCGTTG-3' and 5'- AAAACC TCTAGAGTTGCTCAGCAGCAGCTGGT-3' for B. subtilis. The ifn gene was digested with BamHI and XhoI restriction enzymes and inserted into pET26b vector (Novagen) for E.coli and pHT254 vector (Mo $\mathrm{Bi}$ Tec) for B. subtilis at the BamHI-XhoI site. pHT254-IFN recombinant vector was inserted with the nucleotide sequence (ATG AAC ATC AAA TTC GCA AAA CAA GCA ACA GTT CTT ACA TTC ACA GCA CTT GCA GGC GCA ACA CAA GCA TTC GCA) [54] which encode the signal peptide from the levansucrase of $B$. subtilis before the IFN- $\alpha$ gene for extracellular production of recombinant IFN- $\alpha$. The recombinant vector encoding IFN was transformed into E. coli C43(DE3) and B. subtilis WB800N (Mo Bi Tec) for protein overexpression.

\subsection{IFN- $\alpha$ Overexpression and Purification from E. coli and B. Subtilis}

The optimum conditions for the overexpression of grouper rIFN was investigated at various overexpression time (3, 6, 9, and $12 \mathrm{~h}$ ). The E. coli C43(DE3) and B. subtilis WB800N harboring plasmid encoding IFN was overexpressed upon IPTG induction at optimum conditions, and followed by osmotic shock. The cells were collected by using centrifugation and re-suspended in the Tris- $\mathrm{HCl}$ buffer containing 20\% sucrose and EDTA, pH 8.0 (Osmotic shock buffer 1), and the cells were pelleted again and re-suspended and incubated in the Tris- $\mathrm{HCl}$ buffer containing $5 \mathrm{mM} \mathrm{MgSO} 4$ (Osmotic shock buffer 2) for $30 \mathrm{~min}$. The recombinant IFN was released into the buffer and purified by using a Nickel affinity column (Hitrap chelating column, GE Healthcare), where necessary.

\subsection{Protein Quantification, Western Blot, and Peptide Mass Fingerprinting}

Protein quantification was accomplished using Bradford method [55]. Ten microliters of protein sample was mixed with $200 \mu \mathrm{L}$ of Bradford dye reagent concentrate (Bio-Rad) on a 96-well plate. The plate was kept in dark for $30 \mathrm{~min}$ for color development, followed by the absorbance measurement at $595 \mathrm{~nm}$. A calibration curve was generated using bovine serum albumin as a standard, and made by plotting the concentration against the OD595 and fitting the data by linear regression. Expression of the IFN was analyzed using SDS-PAGE. After separation proteins from the gels were transferred to a PVDF (Polyvinylidene difluoride) membrane and probed with a mouse anti-polyhistidine primary antibody. The PVDF membrane was then incubated with a goat anti-mouse IgG-AP (alkaline phosphatase) conjugate as a secondary antibody, and the proteins were identified by using a colorimetric AP conjugate substrate kit (GE Healthcare). Protein LC-MS analyses were performed on a Waters Acquity nano-UPLC in line with a Waters G2 Q-TOF mass spectrometer. Trypsin-digested protein samples $(10 \mu \mathrm{g} / \mathrm{mL})$ were directly infusion onto mass spectrometer through a syringe pump with flow rate $1 \mu \mathrm{L} / \mathrm{min}$. The G2 Q-TOF mass spectrometer was run in positive ion, high resolution mode with detection in the range of 600 to $2300 \mathrm{~m} / \mathrm{z}$. Source parameters were as follows: capillary voltage, $2.50 \mathrm{kV}$; source temperature, $90^{\circ} \mathrm{C}$; desolvation temperature, $200^{\circ} \mathrm{C}$; cone gas flow: $20 \mathrm{~L} / \mathrm{h}$; the desolvation gas flow, $500 \mathrm{~L} / \mathrm{h}$. The protein peak was deconvoluted by the MassLynx MaxEnt1 function according to the following parameters: output resolution, 1.0 Da/channel; output mass range, 35-85 kDa; uniform Gaussian width at half height, $0.75 \mathrm{Da}$; minimum intensity ratios, $30 \%$ for left and right; iteration to convergence for completion.

\subsection{Mx Gene Expression in the Cells}

The head kidney cells (GK cells) from E. awoara were incubated with $1 \mu \mathrm{g} / \mathrm{mL}$ purified recombinant IFN expressed from E.coli and B. subtilis, and polyinosinic:polycytidylic acid (poly(I:C)) $(50 \mathrm{mg} / \mathrm{mL})$ (Sigma-Aldrich, St. Louis, MO, USA), a positive control, individually. Total RNA was extracted 
using the TRIzol reagent (Invitrogen, Carlsbad, CA, USA), and the first strand cDNA was synthesized from $1 \mathrm{mg}$ of total RNA using the Hi-Script I reverse transcriptase (Bionovas, Toronto, ON, Canada). Real-time PCR was conducted to quantify $M x$ gene expression in the IFN-treated cells compared to the control. The assay was performed on a 7500 Real-Time PCR System (Applied Biosystems, Foster City, CA, USA) using Mx and b-actin gene-specific primers. The real-time PCR reaction was performed with an initial denaturing step of $95^{\circ} \mathrm{C}$ for $10 \mathrm{~min}$, followed by 40 cycles of $95^{\circ} \mathrm{C}$ for $15 \mathrm{~s}$ and $60^{\circ} \mathrm{C}$ for $1 \mathrm{~min}$, and a 1 cycle melting step. Relative expression of the $M x$ gene was normalized to orange-spotted grouper b-actin and calculated as $2^{-\Delta \Delta C T}$. All of the sample was repeated in triplicate for each time point.

\subsection{Cytotoxicity Test and Antiviral Effect of IFN}

The cultured GK cells were washed with trypsin, and the cell suspension was mixed with L-15 ( $2 \%$ FBS) and cultured in a 96-well plate for one day with a cell density of 300,000 cells/well. After incubation, $10 \mu \mathrm{L}$ of different concentrations $(1,5,10,20 \mu \mathrm{g} / \mathrm{mL})$ of IFN was added to each well. The cell viability at $24,48,72 \mathrm{~h}$ was analyzed by MTT assay. To examine the antiviral effect of IFN, GK cells were pre-treated with $1 \mu \mathrm{g} / \mathrm{mL}$ IFN for $24 \mathrm{~h}$ prior to NNV challenge [at a multiplicity of infection (MOI) of 1]. For the co-treatment group, the GK cells were co-treated with $1 \mu \mathrm{g} / \mathrm{mL}$ IFN and NNV simultaneously in 12-well plates. Cells incubated with culture medium without any treatment and infected with NNV were used as the control and positive control, respectively. The reduction of cytopathic effects (CPE) following IFN pre- and co-treatment $(1 \mu \mathrm{g} / \mathrm{mL})$ in GK cells infected with NNV at MOI of 1 in 96-well plates were examined using the MTT assay. During the $48 \mathrm{~h}$ incubation period, the cell morphology was examined daily using a phase contrast microscope and images were obtained to document the appearance of cytopathic effects. All of the sample was repeated in triplicate at each time point.

\subsection{Statistical Analysis}

Data were statistically analyzed using SPSS Version 12.0 (SPSS Inc., Chicago, IL, USA). One-way analysis of variance (ANOVA) was used to determine the statistical differences between the sample means, with the level of significance set at $p<0.05$ or 0.01 . Multiple comparisons of the means were conducted using the Tukey test. All data are expressed as mean \pm SD.

\section{Conclusions}

Herein, we provide a strategy for heterologous overexpression of soluble and functional grouper interferon by taking advantage of bacterial strains and signal peptides. Recovery of recombinant proteins from periplasmic and extracellular spaces are often beneficial for protein purification, folding, and reducing associated costs. Soluble interferons were collected, purified, and evaluated in terms of immune responses and antiviral activity. This technology has great potential for commercial grouper interferon production as a promising product in aquaculture for treating viral infections.

Author Contributions: H.-T.V.L. and M.-W.L. conceived and designed the experiments; H.-J.L., J.T.X.J., W.-J.L., M.-Y.H., T.-H.S., S.-P.L., Y.-C.L., Y.-C.T. performed the experiments; H.-J.L. analyzed the data; H.-J.L. and H.-T.V.L. wrote the paper. All authors have read and agreed to the published version of the manuscript.

Funding: This research was funded by the Center of Excellence for the Oceans, National Taiwan Ocean University [NTOU-RD-AA-2019-1-02011-2].

Acknowledgments: This work was supported by the Center of Excellence for the Oceans, National Taiwan Ocean University from The Featured Areas Research Center Program within the framework of the Higher Education Sprout Project by the Ministry of Education (MOE) in Taiwan.

Conflicts of Interest: The authors declare no conflicts of interest. 


\section{References}

1. Hegde, A.; Chen, C.L.; Qin, Q.W.; Lam, T.J.; Sin, Y.M. Characterization, pathogenicity and neutralization studies of a nervous necrosis virus isolated from grouper, Epinephelus tauvina, in Singapore. Aquaculture 2002, 213, 55-72. [CrossRef]

2. Ransangan, J.; Manin, B.O. Genome analysis of Betanodavirus from cultured marine fish species in Malaysia. Vet. Microbiol. 2012, 156, 16-44. [CrossRef] [PubMed]

3. Kuo, H.P.; Chung, C.L.; Hung, Y.F.; Lai, Y.S.; Chiou, P.P.; Lu, M.W.; Kong, Z.L. Comparison of the responses of different recombinant fish type I interferons against betanodavirus infection in grouper. Fish Shellfish Immunol. 2016, 49, 143-153. [CrossRef] [PubMed]

4. Ucko, M.; Colorni, A.; Diamant, A. Nodavirus infections in Israeli mariculture. J. Fish Dis. 2004, 27, 459-469. [CrossRef] [PubMed]

5. Nishizawa, T.; Furuhashi, M.; Nagai, T.; Nakai, T.; Muroga, K. Genomic classification of fish nodaviruses by molecular phylogenetic analysis of the coat protein gene. Appl. Environ. Microbiol. 1997, 63, 1633-1636. [CrossRef]

6. Nishizawa, T.; Mori, K.; Furuhashi, M.; Nakai, T.; Furusawa, I.; Muroga, K. Comparison of the coat protein genes of five fish nodaviruses, the causative agents of viral nervous necrosis in marine fish. J. Gen. Virol. 1995, 76, 1563-1569. [CrossRef]

7. Costa, J.Z.; Thompson, K.D. Understanding the interaction between Betanodavirus and its host for the development of prophylactic measures for viral encephalopathy and retinopathy. Fish Shellfish Immunol. 2016, 53, 35-49. [CrossRef]

8. Chi, S.C.; Lo, B.J.; Lin, S.C. Characterization of grouper nervous necrosis virus (GNNV). J. Fish Dis. 2001, 24, 3-13. [CrossRef]

9. Munday, B.L.; Kwang, J.; Moody, N. Betanodavirus infections of teleost fish: A review. J. Fish Dis. 2002, 25, 127-142. [CrossRef]

10. Oh, M.J.; Gye, H.J.; Nishizawa, T. Assessment of the sevenband grouper Epinephelus septemfasciatus with a live nervous necrosis virus (NNV) vaccine at natural seawater temperature. Vaccine 2013, 31, $2025-2027$. [CrossRef]

11. Tanaka, S.; Mori, K.; Arimoto, M.; Iwamoto, T.; Nakai, T. Protective immunity of sevenband grouper, Epinephelus septemfasciatus Thunberg, against experimental viral nervous necrosis. J. Fish Dis. 2001, 24, 15-22. [CrossRef]

12. Liu, W.; Hsu, C.H.; Chang, C.Y.; Chen, H.H.; Lin, C.S. Immune response against grouper nervous necrosis virus by vaccination of virus-like particles. Vaccine 2006, 24, 6282-6287. [CrossRef] [PubMed]

13. Chien, M.H.; Wu, S.Y.; Lin, C.H. Oral immunization with cell-free self-assembly virus-like particles against orange-spotted grouper nervous necrosis virus in grouper larvae, Epinephelus coioides. Vet. Immunol. Immunopathol. 2018, 197, 69-75. [CrossRef] [PubMed]

14. Wang, Y.D.; Kung, C.W.; Chen, J.Y. Antiviral activity by fish antimicrobial peptides of epinecidin-1 and hepcidin 1-5 against nervous necrosis virus in medaka. Peptides 2010, 31, 1026-1033. [CrossRef] [PubMed]

15. Ohta, T.; Ueda, Y.; Ito, K.; Miura, C.; Yamashita, H.; Miura, T.; Tozawa, Y. Anti-viral effects of interferon administration on sevenband grouper, Epinephelus septemfasciatus. Fish Shellfish Immunol. 2011, 30, 1064-1071. [CrossRef]

16. Kitao, Y.; Kono, T.; Sakai, M. Characterization and expression analysis of type I interferon in common carp Cyprinus carpio L. Comp. Biochem. Physiol. A 2009, 154, S19. [CrossRef]

17. Li, Z.S.; Xu, X.P.; Huang, L.C.; Wu, J.M.; Lu, Q.X.; Xiang, Z.M.; Liao, J.J.; Weng, S.P.; Yu, X.Q.; He, J.G. Administration of recombinant IFN1 protects zebrafish (Danio rerio) from ISKNV infection. Fish Shellfish Immunol. 2010, 29, 399-406. [CrossRef]

18. Wang, L.; Wang, L.; Zhang, H.X.; Zhang, J.H.; Chen, W.H.; Ruan, X.F.; Xia, C. In vitro effects of recombinant zebrafish IFN on spring viremia of carp virus and infectious hematopoietic necrosis virus. J. Interferon Cytokine Res. 2006, 26, 256-259. [CrossRef]

19. Samuel, C.E. Antiviral actions of interferons. Clin. Microbiol. Rev. 2001, 14, 778-809. [CrossRef]

20. Uze, G.; Monneron, D. IL-28 and IL-29: Newcomers to the interferon family. Biochimie 2007, 89, 729-734. [CrossRef] 
21. Lee, S.B.; Esteban, M. The interferon-induced double-stranded RNA-activated human p68 protein kinase inhibits the replication of vaccinia virus. Virology 1993, 193, 1037-1041. [CrossRef] [PubMed]

22. Lin, R.J.; Yu, H.P.; Chang, B.L.; Tang, W.C.; Liao, C.L.; Lin, Y.L. Distinct antiviral roles for human $2^{\prime}, 5^{\prime}$-oligoadenylate synthetase family members against dengue virus infection. J. Immunol. 2009, 183, 8035-8043. [CrossRef] [PubMed]

23. Haller, O.; Kochs, G. Interferon-induced mx proteins: Dynamin-like GTPases with antiviral activity. Traffic 2002, 3, 710-717. [CrossRef] [PubMed]

24. Lu, M.W.; Chao, Y.M.; Guo, T.C.; Santi, N.; Evensen, O.; Kasani, S.K.; Hong, J.R.; Wu, J.L. The interferon response is involved in nervous necrosis virus acute and persistent infection in zebrafish infection model. Mol. Immunol. 2008, 45, 1146-1152. [CrossRef]

25. Guan, Y.X.; Pan, H.X.; Gao, Y.G.; Yao, S.J.; Cho, M.G. Refolding and purification of recombinant human interferon-gamma expressed as inclusion bodies in Escherichia coli using size exclusion chromatography. Biotechnol. Bioprocess Eng. 2005, 10, 122-127. [CrossRef]

26. Reddy, P.K.; Reddy, S.G.; Narala, V.R.; Majee, S.S.; Konda, S.; Gunwar, S.; Reddy, R.C. Increased yield of high purity recombinant human interferon-gamma utilizing reversed phase column chromatography. Protein Expr. Purif. 2007, 52, 123-130. [CrossRef]

27. Larkin, M.A.; Blackshields, G.; Brown, N.P.; Chenna, R.; McGettigan, P.A.; McWilliam, H.; Valentin, F.; Wallace, I.M.; Wilm, A.; Lopez, R.; et al. Clustal W and Clustal X version 2.0. Bioinformatics 2007, 23, 2947-2948. [CrossRef]

28. Altschul, S.F.; Madden, T.L.; Schaffer, A.A.; Zhang, J.; Zhang, Z.; Miller, W.; Lipman, D.J. Gapped BLAST and PSI-BLAST: A new generation of protein database search programs. Nucleic Acids Res. 1997, 25, 3389-3402. [CrossRef]

29. Hamming, O.J.; Lutfalla, G.; Levraud, J.P.; Hartmann, R. Crystal structure of Zebrafish interferons I and II reveals conservation of type I interferon structure in vertebrates. J. Virol. 2011, 85, 8181-8187. [CrossRef]

30. Pettersen, E.F.; Goddard, T.D.; Huang, C.C.; Couch, G.S.; Greenblatt, D.M.; Meng, E.C.; Ferrin, T.E. UCSF chimera-A visualization system for exploratory research and analysis. J. Comput. Chem. 2004, 25, 1605-1612. [CrossRef]

31. Sali, A.; Blundell, T.L. Comparative protein modelling by satisfaction of spatial restraints. J. Mol. Biol. 1993, 234, 779-815. [CrossRef] [PubMed]

32. Shen, M.Y.; Sali, A. Statistical potential for assessment and prediction of protein structures. Protein Sci. 2006, 15, 2507-2524. [CrossRef] [PubMed]

33. Feige, M.J. Oxidative Folding of Proteins: Basic Principles, Cellular Regulation and Engineering; Royal Society of Chemistry: Croydon, UK, 2018.

34. Morehead, H.; Johnston, P.D.; Wetzel, R. Roles of the 29-138 disulfide bond of subtype A of human alpha interferon in its antiviral activity and conformational stability. Biochemistry 1984, 23, 2500-2507. [CrossRef] [PubMed]

35. Hastings, K.T.; Cresswell, P. Disulfide eeduction in the endocytic pathway: Immunological functions of gamma-interferon-inducible lysosomal thiol reductase. Antioxid. Redox Signal. 2011, 15, 657-668. [CrossRef] [PubMed]

36. Kongton, K.; Phongdara, A.; Tonganunt-Srithaworn, M.; Wanna, W. Molecular cloning and expression analysis of the interferon-gamma-inducible lysosomal thiol reductase gene from the shrimp Penaeus monodon. Mol. Biol. Rep. 2011, 38, 3463-3470. [CrossRef]

37. Braun, A.; Kwee, L.; Labow, M.A.; Alsenz, J. Protein aggregates seem to play a key role among the parameters influencing the antigenicity of interferon alpha (IFN-alpha) in normal and transgenic mice. Pharmaceut. Res. 1997, 14, 1472-1478. [CrossRef]

38. Berkmen, M. Production of disulfide-bonded proteins in Escherichia coli. Protein Expr. Purif. 2012, 82, $240-251$. [CrossRef]

39. Diress, A.; Lorbetskie, B.; Larocque, L.; Li, X.G.; Alteen, M.; Isbrucker, R.; Girard, M. Study of aggregation, denaturation and reduction of interferon alpha-2 products by size-exclusion high-performance liquid chromatography with fluorescence detection and biological assays. J. Chromatogr. A 2010, 1217, 3297-3306. [CrossRef] 
40. Meima, R.; Eschevins, C.; Fillinger, S.; Bolhuis, A.; Hamoen, L.W.; Dorenbos, R.; Quax, W.J.; van Dijl, J.M.; Provvedi, R.; Chen, I.; et al. The bdbDC operon of Bacillus subtilis encodes thiol-disulfide oxidoreductases required for competence development. J. Biol. Chem. 2002, 277, 6994-7001. [CrossRef]

41. Chen, Y.M.; Kuo, C.E.; Chen, G.R.; Kao, Y.T.; Zou, J.; Secombes, C.J.; Chen, T.Y. Functional analysis of an orange-spotted grouper (Epinephelus coioides) interferon gene and characterisation of its expression in response to nodavirus infection. Dev. Comp. Immunol. 2014, 46, 117-128. [CrossRef]

42. Petersen, T.N.; Brunak, S.; von Heijne, G.; Nielsen, H. SignalP 4.0: Discriminating signal peptides from transmembrane regions. Nat. Methods 2011, 8, 785-786. [CrossRef] [PubMed]

43. Beacham, I.R. Periplasmic enzymes in gram-negative bacteria. Int. J. Biochem. 1979, 10, 877-883. [CrossRef]

44. Rathore, A.S.; Bilbrey, R.E.; Steinmeyer, D.E. Optimization of an osmotic shock procedure for isolation of a protein product expressed in E. coli. Biotechnol. Prog. 2003, 19, 1541-1546. [CrossRef] [PubMed]

45. Kakeshita, H.; Kageyama, Y.; Ara, K.; Ozaki, K.; Nakamura, K. Enhanced extracellular production of heterologous proteins in Bacillus subtilis by deleting the C-terminal region of the SecA secretory machinery. Mol. Biotechnol. 2010, 46, 320. [CrossRef]

46. Yoon, S.O.; Hirata, R.D.C.; da Silva, A.C.R.; Nguyen, N.Y.; Hirata, M.H. Cloning and expression of soluble recombinant protein comprising the extracellular domain of the human type I interferon receptor 2c subunit (IFNAR-2c) in E. coli. Biotechnol. Lett. 2002, 24, 1443-1448. [CrossRef]

47. Zhu, F.F.; Wang, Q.; Pu, H.F.; Gu, S.S.; Luo, L.; Yin, Z.M. Optimization of soluble human interferon-gamma production in Escherichia coli using SUMO fusion partner. World J. Microb. Biot. 2013, 29, 319-325. [CrossRef]

48. ISO 10993-5:2009—Biological Evaluation of Medical Devices-Part 5: Tests for in vitro Cytotoxicity. Available online: https://www.iso.org/standard/36406.html (accessed on 18 September 2019).

49. Haller, O.; Stertz, S.; Kochs, G. The Mx GTPase family of interferon-induced antiviral proteins. Microbes Infect 2007, 9, 1636-1643. [CrossRef]

50. Ooi, E.L.; Verjan, N.; Hirono, I.; Nochi, T.; Kondo, H.; Aoki, T.; Kiyono, H.; Yuki, Y. Biological characterisation of a recombinant Atlantic salmon type I interferon synthesized in Escherichia coli. Fish Shellfish Immunol. 2008, 24, 506-513. [CrossRef]

51. Miroux, B.; Walker, J.E. Over-production of proteins in Escherichia coli: Mutant hosts that allow synthesis of some membrane proteins and globular proteins at high levels. J. Mol. Biol. 1996, 260, 289-298. [CrossRef]

52. Lai, Y.S.; John, J.A.; Lin, C.H.; Guo, I.C.; Chen, S.C.; Fang, K.; Lin, C.H.; Chang, C.Y. Establishment of cell lines from a tropical grouper, Epinephelus awoara (Temminck \& Schlegel), and their susceptibility to grouper irido- and nodaviruses. J. Fish Dis. 2003, 26, 31-42.

53. Chi, S.C.; Lin, S.C.; Su, H.M.; Hu, W.W. Temperature effect on nervous necrosis virus infection in grouper cell line and in grouper larvae. Virus Res. 1999, 63, 107-114. [CrossRef]

54. Tjalsma, H.; Bolhuis, A.; Jongbloed, J.D.; Bron, S.; van Dijl, J.M. Signal peptide-dependent protein transport in Bacillus subtilis: A genome-based survey of the secretome. Microbiol. Mol. Biol. Rev. 2000, 64, 515-547. [CrossRef] [PubMed]

55. Bradford, M.M. A rapid and sensitive method for the quantitation of microgram quantities of protein utilizing the principle of protein-dye binding. Anal. Biochem. 1976, 72, 248-254. [CrossRef]

(C) 2020 by the authors. Licensee MDPI, Basel, Switzerland. This article is an open access article distributed under the terms and conditions of the Creative Commons Attribution (CC BY) license (http://creativecommons.org/licenses/by/4.0/). 